\title{
State support of small and medium-sized business in Russian Federation
}

\author{
Tatyana Borisova ${ }^{1}$, Elena Vorobey ${ }^{1, *}$ and Tatyana Gvarliani ${ }^{1}$ \\ ${ }^{1}$ Sochi State University, Sovetskaya str., 26a, 354000, Sochi, Russia
}

\begin{abstract}
The article deals with the mechanisms of the state support of small and medium business, the examples of state support policy implementation subjects of this sector of economy in Krasnodar Region are given.
\end{abstract}

\section{Introduction}

The objective of the current study is the term "entrepreneurship". It appeared in the XVIII century. It means a person acting in the circumstances of risk and acquiring for a particular cost of the means of production in order to manufacture the product and further its sale and income. With the passage of time, the economic essence of this term was being revised and supplemented. According to $2^{\text {nd }}$ article of the Civil Code of the Russian Federation, the concept of "entrepreneurship" includes the implementation of independent activities under its own responsibility, oriented to the regular receipt of profits in the process of using its own resources for the sale of products and services, in accordance with the legislative order.

\section{Materials}

The issues of formation and development of small and medium-sized businesses were studied by such authors as Buyankina, V. Ya. Gorfinkel, V. Demkovich, N. E. Egorova, V. G. Ignatov, N. M. Krayeva, M. G. Lapusta, I. B. Levin, L. K. Pyatiletova, L. Son, E. G. Yasin and others.

The importance of studying the problems of small business is reinforced by the fact, as the authors of the majority of research emphasize, that they get less of state and other support, so far the country has not created an infrastructure that ensures the normal operation of small businesses. Underestimation of small business, ignoring its economic and social opportunities in the future may lead to a deepening crisis of the Russian economy.

\section{Results}

\footnotetext{
* Corresponding author: vorobei.sochi@yandex.ru
} 
Small business is not only an essential component of the world market economy, an integral element of the competitive mechanism, but also the most flexible, effective and transparent by its size economic form that mobilizes the financial and productive resources of the population. Today Russian government is trying to provide all kinds of support to this sector of the economy, because the rapid introduction of innovations in this sector is registered, the mobility of technological changes, the introduction of inventions, the rapid growth of services and employment, acute price and non-price competition, leading, on the one hand, to decrease in prices, and on the other hand, to the fact that the consumer receives high quality products and services, the opportunity for the state to receive large amounts of tax revenue - all this is the contribution of small enterprises in the country's economy.

\section{Discussion}

International practice shows that small and medium-sized businesses (SMBs) have a significant impact on the development of the economy, the solution of social problems, the employment growth. Therefore, in today's economy it is very important to implement measures that ensure the successful functioning of the SMB sector and take into consideration the factors that influence its development in the process of choosing an economic strategy.

In developed countries, small business amount for 70-85\% of GDP, in Russia this index does not exceed $21 \%$. Labor productivity in small and medium-sized enterprises in the Russian Federation, according to the Ministry of Economic Development of the Russian Federation, is 2 to 3 times behind the level of developed countries (the United States, Japan, the European Union countries). In the Russian Federation only $4.7 \%$ of citizens of working age are entrepreneurs. In the BRICS countries, a higher indicator value is recorded (Brazil $17.2 \%$, China - $15.5 \%$, India - $6.6 \%$, South Africa - 7\%). In the US, the proportion of citizens starting their own business in the total number of employable population is 13.8 percent.

In the UK, interest in stimulating small business appeared in the 1970s during the conservatives' pre-election campaign. Currently, every eighth person is an entrepreneur, $36 \%$ of the entire workforce is employed in the SMB. Until that time, most of the employable population was employed by public sector enterprises. Realizing the fact that further development of the country is impossible without the development of small and medium-sized businesses, measures were taken to encourage the population to open private firms.

In developed countries, small and medium business is the driver of economic development, in Russia this sector does not reach the required level.

Since 2008, legislators have adopted a number of basic legal and regulatory acts for the development of small and medium-sized business that regulate the activities of representatives of this sector of the economy.

In accordance with the criteria for referring to small and medium-sized businesses, up to 250 people can work at medium-sized enterprises, up to 100 people - in small enterprises, and at micro enterprises - up to 15 people.

Resolution of the Government of the Russian Federation No. 265 of April 4, 2016 "On the Limit Values of Income Obtained from the Implementation of Entrepreneurial Activity for Each Category of Small and Medium-Sized Entities" establishes restrictions on the revenue: for medium-sized enterprises - 2 billion rubles per year, for small businesses - 800 million rubles per year, for micro enterprises - 120 million rubles per year.

For enterprises, there is a third criterion of referring to the small and medium business sector - the structure of the authorized capital. There are restrictions for state-owned enterprises. They can not relate to small and medium-sized businesses. 
SMBs all over the world face problems, both endogenous and exogenous, that hamper their development. Experts on the results of surveys of Russian entrepreneurs identified 4 main factors constraining the development of small and medium-sized enterprises:

- limited access to financing;

- uncomfortable business climate - small business, as a rule, creates niches of mass demand: these are the retail and services that are now represented on the market by large companies, negative impact of monopolies' network;

- problems with staff - an insufficiently developed business environment. It is about the lack of entrepreneurial culture, the lack of a systematic state education program on the basis of secondary and higher educational institutions aimed at developing entrepreneurial skills, obtaining the foundations of economic theory and financial literacy, low social activity of our citizens;

- problems with sales markets - this sector can become the main driving force of economic transformations due to its ability to adapt quickly to changing realities and to find or create new niches in the market.

Small and medium-sized enterprises form the sector of economy that has already take up its position on the market, performing a number of socio-economic functions, but which still needs state support. Support of small businesses is carried out in the following areas:

- financial - allocation of funds from budgets;

- property - transfer to possession or use of land plots, buildings, structures, equipment, vehicles;

- information - the creation of special information systems;

- consulting - creation of special consulting organizations or compensation of expenses;

- in the field of training and professional development of employees;

- in the field of innovation and industrial production;

- in the field of handicraft activities;

- subjects engaged in foreign economic activity;

- subjects engaged in agricultural activities.

The emphasis in the regions should be made on competitive markets. For a long time the practice of state support in the sphere of SMB development in Russia has been declared and a lot of measures have been taken, some should be noted:

- reduction of administrative pressure;

- reduction of fiscal burden;

- relief in the sphere of registration and licensing of business activities.

Since 2005, the Ministry of Economic Development of Russia has been implementing a special program to provide subsidies from the federal budget to the budgets of constituent entities of the Russian Federation in order to provide state support to small and mediumsized enterprises at the regional level. Within the framework of the program, the funds are allocated on a competitive basis between regions to implement the activities envisaged by the regional programs for the development of small and medium-sized businesses, providing co-financing from the region.

Within the framework of the program, both direct and indirect measures for supporting small and medium-sized businesses are envisaged, including:

- support for small business start-ups;

- support and development of youth entrepreneurship;

- creation and development of a support infrastructure;

- creation of guarantee funds in order to provide guarantees for obligations (loans, leasing agreements, etc.);

- assistance to the development of microfinance organizations that allow small businesses to gain access to borrowed funds. 
In 2015, the President of the Russian Federation established a special institute, the Small and Medium Enterprise Development Corporation, which acts as a state institution for the development of small and medium-sized enterprises in order to provide financial, infrastructure, property, legal, methodological and other support. Including attraction of investments from Russian and foreign companies in the development of SMBs, increasing the share of goods and services purchased by state institutions from small and mediumsized enterprises, ensuring the improvement of state support measures for small and medium-sized businesses.

In 2016, the regions received federal budget funds in the amount of 11.1 billion rubles for the provision of subsidies, guarantees, microloans, the creation and operation of organizations that form the infrastructure for supporting small and mediumsized businesses (business incubators, export support centers, competence centers in the field of innovation and industrial production, capital construction projects). The network of regional organizations of the infrastructure for supporting small and medium-sized businesses has been expanded: 321 competence centers have been established.

However, at the moment no significant result has been achieved.

According to the Federal State Statistics Service, the growth of small enterprises in 2016 compared to the previous year was only $2.1 \%$, but the increase was noted against the background of a decrease in the number of medium-sized firms.

The Krasnodar Territory has been involved in supporting small and medium-sized businesses for a long time and effectively, which is confirmed by the fact that the Krasnodar Territory is one of the leaders in the number of small and medium-sized businesses.

Table 1. The number of small and medium-sized businesses - individual entrepreneurs per 1000 people (2015).

\begin{tabular}{|l|c|}
\hline \multicolumn{1}{|c|}{ Region } & Index \\
\hline Russian Federation & 19,1 \\
\hline Central Federal District & 15,4 \\
\hline Moscow & 7,2 \\
\hline North-West Federal District & 16,4 \\
\hline Saint-Petersburg & 11,2 \\
\hline Southern Federal District & 29,2 \\
\hline Krasnodar region & 35,6 \\
\hline Rostov region & 27,7 \\
\hline North-Caucasian Federal District & 18,6 \\
\hline Far Eastern Federal District & 23,6 \\
\hline The Republic of Sakha (Yakutia) & 35,2 \\
\hline Stavropol region & 28,6 \\
\hline Volga Federal District & 18,9 \\
\hline Ural federal district & 19,1 \\
\hline Siberian Federal District & 18,7 \\
\hline Magadan Region & 37,7 \\
\hline Crimean Federal District & 29,3 \\
\hline city of Sevastopol & 32,5 \\
\hline
\end{tabular}

By the number of medium-sized enterprises there is a tendency to increase, as well as in the whole country, and in the separately considered region - Krasnodar Region, which is presented in Table 2 . 
Table 2. Number of medium-sized enterprises (including geographically isolated units) in 2016 (units).

\begin{tabular}{|c|c|c|c|c|}
\hline \multirow{2}{*}{ Region } & \multicolumn{4}{|c|}{ Number of medium-sized enterprises (units) } \\
\cline { 2 - 5 } & \multicolumn{4}{|c|}{ J016 г. } \\
\cline { 2 - 5 } & January-March & January-June & January-September & January-December \\
\hline $\begin{array}{c}\text { Russian } \\
\text { Federation }\end{array}$ & 14773 & 15598 & 16091 & 16308 \\
\hline $\begin{array}{c}\text { Central } \\
\text { Federal } \\
\text { District }\end{array}$ & 3821 & 3998 & 4108 & 4166 \\
\hline $\begin{array}{c}\text { Moscow } \\
\text { region }\end{array}$ & 792 & 820 & 844 & 876 \\
\hline Moscow & 787 & 873 & 908 & 924 \\
\hline $\begin{array}{c}\text { Leningrad } \\
\text { region }\end{array}$ & 199 & 208 & 220 & 218 \\
\hline $\begin{array}{c}\text { Krasnodar } \\
\text { region }\end{array}$ & 645 & 696 & 718 & 727 \\
\hline
\end{tabular}

In Russia the following areas of small and medium-sized businesses are being implemented:

- material and information assistance in innovation;

- material and material assistance for participation in exhibitions;

- assistance to entrepreneurs engaged in the agricultural sector;

- tax benefits and tax holidays for newly established enterprises;

- partial reimbursement of expenses for the renewal of fixed assets;

- reimbursement of expenses for training of employees of the enterprise;

- information support (organization of seminars, training courses);

- creation of a comfortable environment for entrepreneurship, business incubators, funds;

- property support, provision of municipal premises and production facilities with a discount up to $60 \%$;

- support for regional investors, soft loans and partial compensation of expenses under leasing contracts;

- partial reimbursement of expenses for the implementation of energy saving programs;

- the placement of government orders, admission to tenders for public procurement;

- direct financial support.

Several forms of state support are being implemented in the Krasnodar Region. All of them are executed within the framework of the Resolution of the Head of Administration (Governor) of the Krasnodar Territory of 14.10.2013 №1201 "On the approval of the state program of Krasnodar region" Economic development and innovative economy". Within this program, a subprogram was approved for subsidizing from the regional budget a part of the cost of down payment under a leasing contract incurred by small and medium-sized business entities, as well as supporting innovative companies.

The Krasnodar Region the fund for support and a microfinance has been established. In order to ensure access of small and medium-sized business to financial resources through the provision of microloans, which is engaged in the Non-Profit Organization "Microfinance Fund for Small and Medium-Sized Enterprises of the Krasnodar Region".

The main activity of the fund is the provision of micro-loans to small and medium-sized businesses and organizations of infrastructures and support for small and medium-sized businesses in the Krasnodar Region in the amount of up to 1 million rubles for a period of up to one year. The Guarantee Fund was established on September 11, 2009 within the framework of the regional target program of state support of small and medium-sized 
businesses. The founder is the administration of the Krasnodar Territory represented by the Ministry of Strategic Development, Investments and Foreign Economic Affairs. The main activity of the guarantee fund is the provision of guarantees on bank loans.

In fact, the guarantee of the fund replaces the collateral for the loan. At present, the amount of the guarantee capital of the fund is 530 million rubles. Guarantee capital serves as collateral for the fund provided by guarantees. As of the current date, the Fund provided 195 guarantees for a total of 649 million rubles, which made it possible to provide loans to small and medium-sized businesses for a total of more than 1 billion rubles (1230 million rubles).

Free assistance is provided jointly with the Center for Support of Entrepreneurship within the framework of the implementation of the subprogram "State Support of Small and Medium-Sized Enterprises in the Krasnodar Territory for 2014-2018" of the state program of the Krasnodar Region "Economic Development and Innovative Economy". The Center for Entrepreneurship Support works on the principle of "one window", where the entrepreneur receives a full range of consultations on all issues of interest to him.

Here are statistical data on the number of small and medium-sized enterprises registered in Russia in 2017:

- 5925282 small and medium-sized enterprises were registered in Russia in the register of small and medium-sized enterprises in February 2017;

- 5636789 units were microenterprises (95\%);

- 267558 - small enterprises $(4.5 \%)$;

- 20935 - medium-sized enterprises $(0.4 \%)$;

- individual entrepreneurs are 3074668 units of small and medium business (52\%);

- legal entities are 2850614 units of small and medium business (48\%).

The Government of the Russian Federation approved a target model for the "Support of Small and Medium-sized Entrepreneurship". Its implementation in the subjects of the Federation is planned in 2017. In addition, the Presidium of the Council under the President of the Russian Federation for Strategic Development and Priority Projects approved the provisions of the priority project on the main direction of the strategic development of the Russian Federation "Small Business and Support for an Individual Business Initiative". The purpose of which is to increase the number of people employed in the sphere of small business. The long-term target program of Krasnodar Region "State support of small and medium-sized business in the Krasnodar Territory" for 2013 - 2017 is functioning.

For the first time in the field of small and medium-sized business development, a strategic planning document for the long-term perspective has been approved - the Strategy for the Development of Small and Medium-sized Entrepreneurship in the Russian Federation for the period up to 2030 (the "Strategy"). This Strategy contains a concept of social entrepreneurship. It also includes innovative activities initially aimed at addressing or alleviating the social problems of society on the terms of self-sufficiency and sustainability, the increase of number of small and medium-sized businesses in the field of social services, as well as increasing targeting, including number in the following areas:

1) special tax regimes, simplified rules for maintaining tax accounting, simplified forms of tax returns for individual taxes and fees for small businesses;

2) simplified methods of accounting, including simplified accounting (financial) reporting, and a simplified procedure for conducting cash transactions for small businesses;

3) simplified procedure for compiling statistical reports by small and medium-sized businesses;

4) preferential procedure for settlements for state and municipal property privatized by small and medium-sized business entities;

5) peculiarities of participation of small business entities as suppliers (executors, contractors) in procurement of goods, works, services for state and municipal needs, as well 
as peculiarities of participation of small and medium-sized business entities in procurement of goods, works, services by separate types of legal entities;

6) measures to ensure the rights and legitimate interests of small and medium-sized businesses in the implementation of state control (supervision);

7) measures to ensure financial support for small and medium-sized businesses, organizations that form the infrastructure for supporting small and medium-sized businesses;

8) measures to develop the infrastructure for supporting small and medium-sized businesses;

9) other measures aimed at ensuring the implementation of the goals and principles of this Federal Law.

In developed countries, the SMB sector is mainly implemented through management strategies that enable it to fulfill the most important task of a market economy - the development and preservation of a competitive environment, which, through a cost-cutting mechanism, encourages producers to use more efficient technologies.

The main role in supporting and developing SMBs in the UK is played by the policy pursued by the state in various directions: lower corporate tax rates for small firms, a mechanism for deferred payment of bills and a system of discounts for the repayment of overdue loans, etc. The SMB lending system has been introduced and is successfully operating. There is comprehensive assistance to start-up enterprises. The interaction of large business with SMBs is supported at the state level.

At the level of various ministries, SMB support programs have also been developed. For example, companies that provide consulting support to new and existing firms are being created. Also the financial support for SMBs through a system of various kinds of grants is of great importance. To solve the problems of small and medium-sized businesses, analyze the current economic situation in the country and legislative regulation, the Department for Business, Energy and Industrial Strategy, which is supported by various ministries, operates.

Priority areas for SMB support in the UK are:

- creating a balance between the public and private sectors of the economy;

- acquisition and improvement of professional skills, training;

- support for trade (including exports) and entrepreneurship.

The main feature of small and medium business in the world is flexibility, depending on changes and market requirements. Based on modern research conducted by world economists, it is possible to single out the main strategies for managing small and mediumsized businesses:

1. Copy strategy - a small or medium enterprise uses the results of scientific research and other works of larger enterprises on original products, tries to produce copies of these products at prices and quality incomparably inferior to the original.

2. The strategy of optimal size - the firm adopts the motto: "do not stick out" beyond the market niche in which it is engaged. This strategy of management can ensure the survival of the enterprise, but serves as an obstacle to the expansion of the company that chose this strategy.

3. The strategy of participation in the product of a large enterprise - a separate small element of the products of a larger company becomes the final product for an enterprise from the small or medium business sector.

4. The strategy of using the advantages of a large company (franchising) - in accordance with this strategy, between a small or medium-sized firm and a large enterprise, a contract is concluded according to which the small company's obligation to supply its own goods, services, etc. becomes an obligation of a large company, provided that a small firm will 
have business relations only with this large company, in addition, it must transfer the share specified by the contract from the amount of sales.

\section{Conclusions}

Support to the SMB sector should not only be provided, but should be effective. The implementation of government measures requires the formation of a flexible organizational structure in the field of support and development of entrepreneurship, based on close interaction of the state and business, further development and enhancing the effectiveness of the dialogue between them.

Within the framework of the SMB Development Strategy in Russia up to 2030, approved on June 2, 2016, it is necessary to intensify the state support of entrepreneurs in the form of:

- grants and subsidies;

- lending;

- microfinance;

- guarantees and sureties;

- refinancing and securitization - attraction of financing through the issue of securities;

- leasing, factoring - financial services, produces and supplier of employees on deferred payment terms, crowd funding (collective cooperation of people who unite voluntarily money or other resources, via the Internet, to support other people).

In addition, within the framework of this strategy an accessible automated information and analytical system is created, it is planned to facilitate the access of small and mediumsized businesses to real estate objects.

Using the listed levers, the government plans to increase: the number of entrepreneurs in the SMB sector, the share of its turnover, the employment of the country's population, the development of the national economy.

The interregional rating on attractiveness for business, which includes 35 regions of Russia, is presented in Table 3.

Table 3. Interregional rating on attractiveness for business, which includes 30 regions of Russia.

\begin{tabular}{|c|c|c|c|}
\hline Position & Region & Position & Region \\
\hline 1 & Novosibirsk region & 16 & Perm Region \\
\hline 2 & Sverdlovsk region & 17 & The Republic of Buryatia \\
\hline 3 & Moscow & 18 & Ulyanovsk region \\
\hline 4 & Krasnodar region & $19-20$ & Krasnoyarsk region \\
\hline $5-6$ & Chelyabinsk region & $19-20$ & Tula region \\
\hline $5-6$ & Samara Region & $21-22$ & Omsk Region \\
\hline 7 & Republic of Bashkortostan & $21-22$ & Irkutsk region \\
\hline 8 & Voronezh region & $23-24$ & Yaroslavl region \\
\hline 9 & Republic of Tatarstan & $23-24$ & 25 \\
\hline 10 & Belgorod region & & \\
\hline
\end{tabular}




\begin{tabular}{|c|c|c|c|}
\hline 11 & Nizhny Novgorod Region & 26 & Ryazan Oblast \\
\hline 12 & Rostov Region & 27 & Arkhangelsk region \\
\hline 13 & Lipetsk region & 28 & Novgorod region \\
\hline $14-15$ & Moscow region & 29 & Tver region \\
\hline $14-15$ & St. Petersburg & 30 & Astrakhan Region \\
\hline
\end{tabular}

Krasnodar region takes the 4th place. It is important to pay attention to the attractors that the first 3 regions have. Today, the region's competitiveness no longer depends solely on geographical location or natural resources. For example, the leadership of the Novosibirsk region (1st place) is determined by the location of the most important hub of the country (developed infrastructure). At the same time, the level of the gross regional product, labor productivity and the level of salaries are rather low.

Krasnodar Territory (4th place) is attractive (has a strong basis) for antimonopoly policy, level of security and development of the financial sector (availability of credit, financial services for business).

Success depends on the activity of regional authorities, the quality of human resources and infrastructure, according to Sberbank research of the competitiveness of Russian regions [2].

\section{References}

1. The Civil Code of the Russian Federation

2. https://finance.rambler.ru/news/ratings/115873761.html

3. http://www.gks.ru.

4. E.K. Vorobey, T.E. Gvarliani, A.S. Nubaryan, Proceedings of the Sochi State University 3, 1(36) (2015) 